\title{
SOIL MICROBIAL AND PHYSICOCHEMICAL CHANGES AFTER THE ADDITION OF BIOCHAR, BACTERIAL INOCULUMS AND NITROGEN FERTILIZER
}

\author{
Irina Mikajlo1,2, Bertrand Pourrut'²,3 Brice Louvel ${ }^{2}$, Jaroslav Hynšt', \\ Jaroslav Záhora ${ }^{1}$
}

\footnotetext{
${ }^{1}$ Department of Agrochemistry, Soil Science, Microbiology and Plant Nutrition, Faculty of AgriSciences, Mendel University in Brno, Zemědělská 1, 61300 Brno, Czech Republic

${ }^{2}$ University Lille, IMT Lille Douai, University Artois, Yncrea Hauts-de-France, ULR 4515 - LGCgE, Laboratoire de Génie Civil et géo-Environnement, F-59000 Lille, France

${ }^{3}$ EcoLab, Université de Toulouse, CNRS, INPT, UPS, Toulouse, France, ENSAT - Avenue de l'Agrobiopole, 31326 Auzeville-Tolosane, France
}

Link to this article: https://doi.org/10.11118/actaun.2021.045

Received: 20. 4. 2020, Accepted: 28. 6. 2021

To cite this article: MIKAJLO IRINA, POURRUT BERTRAND, LOUVEL BRICE, HYNŠT JAROSLAV, ZÁHORA JAROSLAV. 2021. Soil Microbial and Physicochemical Changes After the Addition of Biochar, Bacterial Inoculums and Nitrogen Fertilizer. Acta Universitatis Agriculturae et Silviculturae Mendelianae Brunensis, 69(4): 501-510.

\begin{abstract}
Addition of biochar is often proposed as an improving agent of soil properties. The combination of biochar (BCH) with mineral or biological amendments in order to improve its influence on soil-plant properties compared to the unamended BCH was vastly studied. Bacterial inoculums as a promising additive to $\mathrm{BCH}$ amendment are highly dependent on $\mathrm{BCH}$ quantity, its feedstock and soil state. Luvisol from a protection zone of water sources was used in pot experiment set-up. The changes in physicochemical properties (pH, cation-exchange capacity - CEC) and biological soil activities (soil enzymes: urease, phosphatase and laccase activity and total bacteria content) after the addition of beech wood biochar combined with the addition of bacterial inoculums (Bacofil and Novarefm) and nitrogen fertilizer after two growing cycles of Lactuca sativa var. capitata were studied using spectrophotometry methods. Increased $\mathrm{pH}$ and $\mathrm{CEC}$ values were detected in biochar amended treatments. The increase of laccase activity claimed on $\mathrm{BCH}$ additives promoting effect, especially in a case of Bactofil inoculum amendment. Nevertheless, BCH suppressed acid phosphatase activity in all the $\mathrm{BCH}$ additives equally. Whereas urease activity and total soil bacteria extraction remained unchanged in $\mathrm{BCH}$ amended treatments compared to control.
\end{abstract}

Keywords: biochar, enzyme activity, fertilizer, inoculum, lettuce, nitrogen, soil bacteria

\section{INTRODUCTION}

Soil degradation stands for a durable descent in soil productivity, quality and its environment moderating ability (Lal, 2001). Widespread degradation factors in Czech Republic include soil erosion, soil compaction, loss of organic matter (OM), soil acidification, and soil contamination (Šarapatka and Bednář, 2015).
Biochar (BCH) has gained widespread attention as a mean to balance soil degradation, while being able to sequester carbon into soils. BCH derives from the carbonization of biomass and is a stable solid material for many years in soil (Lehmann, 2007). It could increase soil fertility (Chan et al., 2007) and enhance agricultural productivity (Major et al., 2010) by increasing cation exchange capacity and 
nutrient cycling with the ability of soils to retain plant available water, decrease soil bulk density, increase pH (Laird et al., 2010) and additionally BCH is a habitat for microorganisms which generally increases microbial biomass (Lehmann et al., 2011; Ippolito et al., 2012).

High diversity of microbial community structure is involved in efficient nutrient transfer to crops and nutrient conservation in soil (Gul et al., 2015). BCH alters positively soil microbial abundance and community composition (Domene et al., 2014), affects microbially-mediated nutrients transformation in soil (Kuppusamy et al., 2016) that eventually leads to changes in nutrient availability and crop productivity (Spokas et al., 2012). Generally, BCH effects on soil enzyme activities are variable, depending on soil type and on the particular enzyme (Bailey et al., 2011). For instance, soil extracellular enzymes that are involved in carbon (C) and sulphur cycling, increased while amended with the lower amount of $\mathrm{BCH}(0.5 \%$ by mass), whereas higher $\mathrm{BCH}$ amounts decreased their activity (Wang et al., 2015). Lammirato et al. (2011) concluded that BCH is inclined to soil enzymes adsorption without complete loss of their potential activity. Particularly some enzymes like laccases, that are playing a central role in $\mathrm{OM}$ recycling being involved in lignin degradation and humic substances formation, are immobilized by BCH (Li et al., 2018). BCH also reduced urease activity that release inorganic $\mathrm{N}$ into soils (Wu et al., 2013). Other studies claim that BCH improves soil phosphatase activity, which is fundamental to transform organic phosphor (P) into inorganic $\mathrm{P}$, consequently influencing micro-environment (Nèble et al., 2007).

Despite its potential positive effects, $\mathrm{BCH}$ could have negative influence on soils activities and on plant growth (Asai et al., 2009). Thus, co-amendment of BCH with fertilizers (Steiner et al., 2008) or bacterial inoculum (Sun et al., 2016) could mitigate its negative impact and ameliorate $\mathrm{BCH}$ properties. However, there is still a need to understand $\mathrm{BCH}$ influence on soil enzymes, especially after several growing periods, as most of the research focus on the influence of freshly applied $\mathrm{BCH}$.
In this study, we investigated the influence of $\mathrm{BCH}$ combined with other soil amendments (bacterial inoculums and nitrogen (N) fertilizers) on soil physicochemical properties (pH, CEC) and biological activities by choosing soil enzymes involved in $\mathrm{N}$, $\mathrm{P}$ and $\mathrm{C}$ nutrient cycles (urease, phosphatase and laccase activities; total soil bacteria extraction) after two growing periods of lettuce (Lactuca sativa L.).

\section{MATERIALS AND METHODS}

\section{Soil Sampling}

Soil was collected from experimental plots situated in the protection zone of underground drinking water source "Brezova nad Svitavou" (Czech Republic; 4940.409'N, 16²7.545`E.) Soil was sampled with a spade according to Czech Technical Standard ISO 10 381-6 from the topsoil horizon (till $0-30 \mathrm{~cm}$ ) in summer 2015. The soil is classified as sandy loam Luvisol (Tab. I). Fresh soil samples have been delivered to the laboratory where they have been air-dried, homogenized and sieved through a $10 \mathrm{~mm}$ sieve.

\section{Biochar Material}

Beech wood biochar (Fagus silvatica L.) has been originated from Czech Republic (company BIOUHEL.CZ s.r.o.) produced by slow pyrolysis with the use of low temperature $470{ }^{\circ} \mathrm{C}$ (Tab. II).

\section{Experimental Design}

Five different types of treatments including a control have been prepared (Tab. III). Four replications of each treatment resulted into twenty plastic square containers $(10 \times 10 \times 11 \mathrm{~cm})$ filled with $800 \mathrm{~g}$ of topsoil.

$\mathrm{BCH}$ was freshly applied in the quantity of $6 \%$ per pot with the first plant growing cycle. The $\mathrm{BCH}$ quantity used for the experiment was chosen as a high concentration in order to obtain distinguished results (Chan et al., 2007).

Pots were split into two groups. Half of them were inoculated with the commercial bacterial inoculums "Bactofil" (BI1) from BioFil Ltd (Budapest, Hungary) while the other half were

I: Basic properties of soil used in experiment (adapted from Plošek, 2016)

\begin{tabular}{|c|c|c|c|c|c|c|c|c|c|c|c|}
\hline \multirow{2}{*}{$\begin{array}{c}\text { CEC } \\
\left(\mathrm{cmol} \mathrm{kg}^{-1}\right)\end{array}$} & \multirow{2}{*}{$\begin{array}{c}\mathrm{pH} \\
\left(\mathrm{H}_{2} \mathrm{O}\right)\end{array}$} & \multirow{2}{*}{$\begin{array}{l}\text { Conductivity } \\
\left(\mu \mathrm{S} \mathrm{cm}^{-1}\right)\end{array}$} & $\mathrm{N}_{\text {tot }}$ & $\mathrm{C}_{\text {tot }}$ & $\mathrm{C}_{\text {org }}$ & \multirow{2}{*}{$\mathrm{C} / \mathrm{N}$} & \multirow{2}{*}{$\begin{array}{c}\text { Humus } \\
\text { content } \\
(\%)\end{array}$} & $\mathrm{P}$ & $\mathrm{K}$ & $\mathrm{Ca}$ & $\mathrm{Mg}$ \\
\hline & & & & $\mathrm{mg} \mathrm{g}^{-1}$ & & & & \multicolumn{4}{|c|}{$\left(\mathrm{mg} \mathrm{kg}^{-1}\right)$} \\
\hline 10.333 & 6.3 & 106.4 & 1.6 & 17.7 & 11.3 & 19.8 & 1.95 & 180.6 & 167.8 & 1449 & 52.5 \\
\hline
\end{tabular}

II: Physicochemical characteristics of studied biochar

\begin{tabular}{|c|c|c|c|c|c|c|c|c|c|}
\hline \multirow{2}{*}{$\mathrm{pH}$} & \multirow{2}{*}{$\begin{array}{l}\text { Conductivity } \\
\left(\mathrm{mS} \mathrm{cm}^{-1}\right)\end{array}$} & Dry matter & $\mathrm{N}_{\text {tot }}$ & $\mathrm{C}_{\text {tot }}$ & Ash & $\mathrm{P}$ & $\mathrm{K}$ & $\mathrm{Ca}$ & $\mathrm{Mg}$ \\
\hline & & \multicolumn{4}{|c|}{ (\%) } & \multicolumn{4}{|c|}{$\left(\mathrm{mg} \mathrm{g}^{-1}\right)$} \\
\hline 10.12 & 4.22 & 95.47 & 0.37 & 56.05 & 32.72 & 2.614 & 16.36 & 51.23 & 6.134 \\
\hline
\end{tabular}


III: Characteristics of all the applied treatments

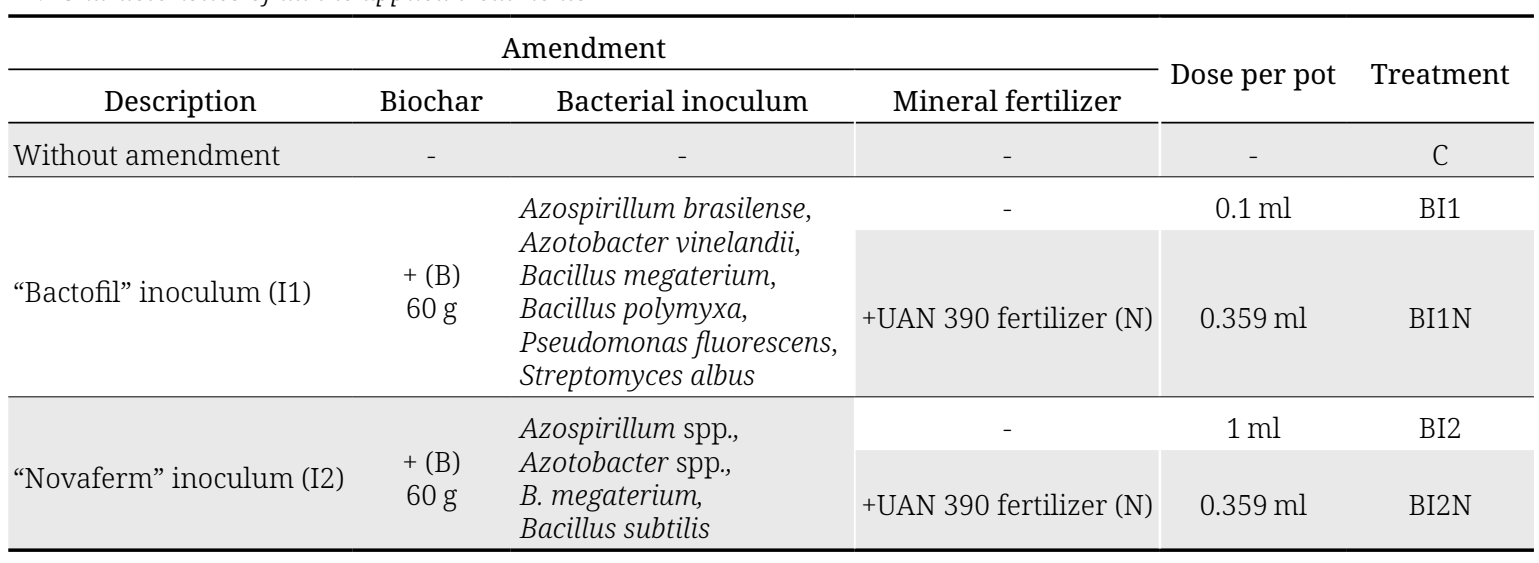

inoculated with "NovaFerm" (BI2) from Nova Scienta Kft (Soltvadkert, Hungary) at the beginning of the experiment on lettuce (BBCH-scale: 13). Later (BBCH-scale 15-18), UAN 390 fertilizer was added to half of the inoculated pots (BI1N and BI2N) at the dose recommended by the supplier $\left(140 \mathrm{~kg} \mathrm{~N} \mathrm{Na}^{-1}\right)$. UAN 390 is a liquid fertilizer of ammonium nitrate with urea and with ammonium $\left(\mathrm{NH}_{4}-\mathrm{N}\right)$ nitrogen, nitrate $\left(\mathrm{NO}_{3}-\mathrm{N}\right)$ nitrogen and amide $\left(\mathrm{N}-\mathrm{NH}_{2}\right)$ nitrogen. It contains $30 \%$ of nitrogen; the ratio of ammonium, nitrate, and amide nitrogen is $1: 1: 2$.

\section{Plant Cultivation and Soil Preparation}

Lactuca sativa var. capitata L. Cv. Kennedy has been chosen as an experimental plant. Each pot contained one plant. The pots were randomly put into a Walk-In Chamber by CLF Plant Climatics $\mathrm{GmbH}{ }^{\circledR}$ growth chamber that was set to maintain temperatures of $22^{\circ} \mathrm{C}$ by day and $19^{\circ} \mathrm{C}$ at night, $65 \%$ humidity, with a day length of $12 \mathrm{~h}$ and light intensity of $380 \mu \mathrm{mol} \mathrm{m} \mathrm{m}^{-1}$. All the pots have been watered by adding $50 \mathrm{ml}$ of deionized water every 2 days.

After two month of one growing cycle, leaf biomass was harvested. Root biomass from the first growing cycle of plants was removed and experimental soils were homogenized again and re-filled into containers. Lettuce plants were seeded again. The inoculation by "Bactofil" and "NovaFerm" additives and the application of UAN 390 fertilizer were done at the same $\mathrm{BBCH}$-scale as in the case of the first two month plant growing cycle.

At the end of the experiment, soils were collected for determination of physicochemical and biological activities. Soil samples were cleared from plant residues and sieved to $2 \mathrm{~mm}$. One part of the soil was used for soil enzyme activity determination, while the rest was transferred into plastic trays to dry at $40^{\circ} \mathrm{C}$ in the oven for $24 \mathrm{~h}$ and used for $\mathrm{pH}$ and CEC measurement.

\section{Soil Physicochemical Parameters}

The 2 mm-sieved soil samples were prepared according to ISO 11464,1994 . $\mathrm{pH}\left(\mathrm{H}_{2} \mathrm{O}\right)$ was measured after stirring a mixture of soil and deionized water
(1:5, v/v) in accordance with the ISO 10390 standard. Cationic exchange capacity (CEC) was analysed after percolation of $\mathrm{CH}_{3} \mathrm{COONH}_{4}(1 \mathrm{M}, \mathrm{pH}=7)$ solution into soil samples followed by an extraction of ammonium ions $\left(\mathrm{NH}_{4}^{+} \mathrm{N}\right)$ with sodium chloride $(\mathrm{NaCl}, 1 \mathrm{M})$ according to the French NF X31-130 standard.

\section{Soil Biological Parameters}

Extraction of indigenous bacterial cells from soil was performed on the two fresh soil samples using a Nycodenz gradient separation method (Lindahl and Bakken, 1995). A white band of bacterial cells were obtained at the interface between the Nycodenz-soil mix particles and the overlying aqueous layer. Ureases activity can be evaluated according to Kandeler and Gerber (1988). The measurement of the urase activity is done through the colorimetric determination of ammonium $\left(\mathrm{NH}_{4}^{+}-\mathrm{N}\right)$ release (Saha et al., 2012). Phosphatase activity was measured according to the protocol of Eivazi and Tabatabai (1977) that is based on the colorimetric estimation of the p-nitrophenol released by the acid phosphatases activity upon soil incubation with buffer solution and the p-nitrophenyl phosphate. The protocol to determine laccase activity uses substrate ABTS: 2,2'-azinobis-(-3-ethylbenzthiazoline-6-sulfonate) then quantifying the rate of oxidation of ABTS to ABTS $^{+}$in the supernatant (Eichlerová et al., 2012).

\section{Data Analysis}

Soil physicochemical properties (pH, CEC) and biological activities (urease, phosphatase and laccase activities; total soil bacteria extraction) are expressed and presented as the means and standard deviations of replicates for each treatment. Analysis of variance (ANOVA) was accomplished to estimate differences within the treatments. The normal distribution of data (Shapiro-Wilk test) and equality of variances (Bartlett test) were checked. When both tests proved conformity, Fisher statistics was considered for significance ( $p \leq 0.05)$ and the Tukey (HSD) test was used for pair-wise comparisons of statistical groups. The Kruskal-Wallis test was 
performed for data that were not distributed normally. All statistic tests were conducted in XLSTAT software (AddinsoftTM software 2016).

\section{RESULTS}

\section{Changes in Soil Physicochemical Parameters}

Soil pH value was significantly increased from neutral value in control soil to highly alkali in biochar amended treatments (Tab. IV).

Bactofil amended soils had pH values higher by 1.2 times compared to control and by 1.02 times compared to the rest of the treatments. BI1N and BI2N treatments had no significant differences resulting into alkali pH fluctuating from 8.0-8.1 that was 1.2 times higher compared to a control.

Control soil showed low CEC data and Bactofil amended treatment was equal $\left(7.4-7.5 \mathrm{cmol} \mathrm{kg}^{-1}\right)$ resulting into the lowest $\mathrm{CEC}$ value compared to the other $\mathrm{BCH}$ amended treatments. The rest of the treatments (BI1N, BI2 and BI2N) exposed significantly higher by 1.1 times CEC values compared to control fluctuating from $8.1-8.2 \mathrm{cmol} \mathrm{kg}^{-1}$. Additionally, BI2N treatment was statistically equal to control CEC value.

\section{Changes in Soil Biological Parameters}

\section{Soil Bacteria Extraction}

The number of bacteria $\mathrm{g}^{-1}$ dry soil in the studied $\mathrm{BCH}$ amended and inoculated Luvisol soil presented in Fig. 1.
No significant differences were found between the treatments concerning soil bacteria extraction. Bacteria quantity in the control soil revealed $151063 \mathrm{~g}^{-1}$ dry soil and this unamended treatment was statistically equal to the rest of $\mathrm{BCH}$ amended treatments where the values ranged from 83821-213004 g-1 dry soil.

\section{Urease Activity}

No significant differences in urease activity were found among all the treatments including control unamended soil (Fig. 2). The control soil exhibited $82.2 \mathrm{mg} \mathrm{NH}_{4}^{+}-\mathrm{N} \mathrm{g}^{-1}$ dry soil that was statistically equal to the rest of $\mathrm{BCH}$ amended treatments that ranged from $98.3-138.9 \mathrm{mg} \mathrm{NH}_{4}^{+}-\mathrm{N} \mathrm{g}^{-1}$ dry soil.

\section{Acid Phosphatase Activity}

Acid phosphatase activity where control soil exposed $0.15 \mu \mathrm{g} \mathrm{Np} \mathrm{g}^{-1}$ dry soil and the rest of $\mathrm{BCH}$ amended treatments (BI1, BI1N, BI2, BI2N) displayed significantly decreased by 2.5 times values compared to control, that fluctuated 0.06$0.07 \mu \mathrm{g} \mathrm{Np} \mathrm{g}^{-1}$ dry soil (Fig. 3).

\section{Laccase Activity}

Laccase activity changes in amended soils after the second plant harvest (Fig. 4).

Laccase activity in control soil was $0.16 \mu \mathrm{mol}$ $\mathrm{ABTS}^{+} \mathrm{g}^{-1}$ dry soil and it was equal to BI2 treatment of $0.24 \mu \mathrm{mol} \mathrm{ABTS}{ }^{+} \mathrm{g}^{-1}$ dry soil. Amended B, BI1N and BI2N treatments had significantly higher by

IV: Soil physicochemical parameters in control soil (C) and in BCH amended soils combined with inoculums (BI1, BI2) and with additional $N$ fertilizer addition (BI1N, BI2N) after the second plant harvest, \pm standard deviation. CEC: cationic exchange capacity, $p H$ (For every parameter, different letters in lines refer to significant differences between soils) (Tukey HSD test, $n=4$, $p \leq 0.05)$.

\begin{tabular}{lccccc}
\hline \multicolumn{1}{c}{ Treatment } & $\mathrm{C}$ & BI1 & BI1N & BI2 & BI2N \\
\hline $\mathrm{pH}$ & $6.8 \pm 0.1 \mathrm{c}$ & $8.3 \pm 0.1 \mathrm{a}$ & $8.0 \pm 0.1 \mathrm{~b}$ & $8.1 \pm 0.0 \mathrm{~b}$ & $8.0 \pm 0.0 \mathrm{~b}$ \\
$\mathrm{CEC}\left(\mathrm{cmol} \mathrm{kg}^{-1}\right)$ & $7.5 \pm 0.1 \mathrm{bc}$ & $7.4 \pm 0.2 \mathrm{c}$ & $8.1 \pm 0.2 \mathrm{a}$ & $8.2 \pm 0.3 \mathrm{a}$ & $8.1 \pm 0.3 \mathrm{ab}$ \\
\hline
\end{tabular}

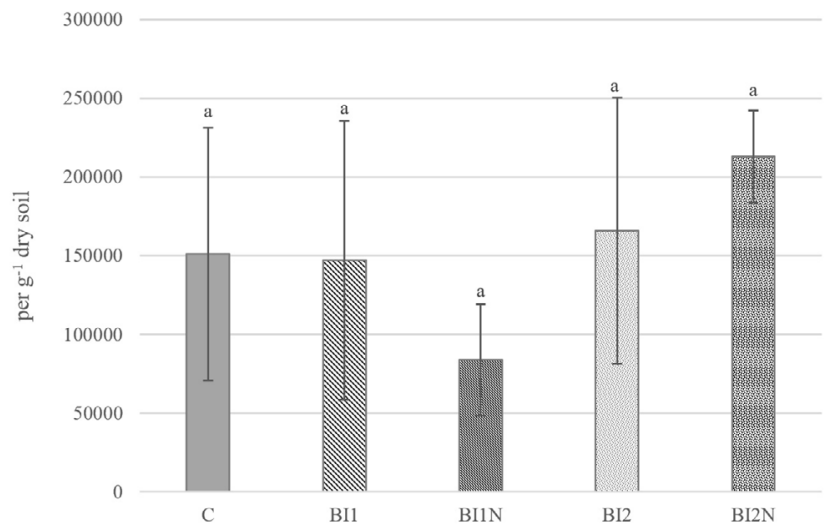

1: Average counts of bacteria (per $g^{-1}$ dry soil) in control soil (C) and in BCH amended soils combined with inoculums (BI1, BI2) and with additional $N$ fertilizer addition (BI1N, BI2N). Values are presented as means \pm SD. Different letters refer to significant differences between treatments (Tukey HSD test, $n=4, p \leq 0.05$ ). 


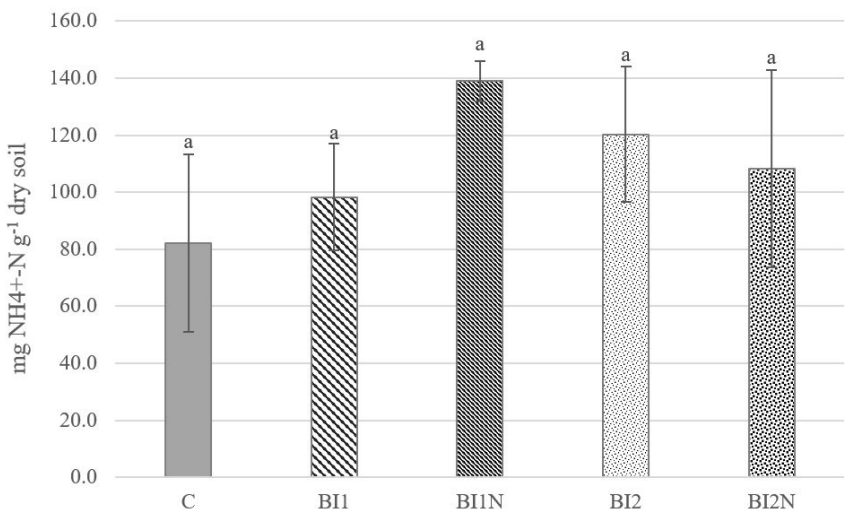

2: Urease activity ( $\mathrm{mg} \mathrm{NH}_{4}^{+}-\mathrm{N}^{-1}$ dry soil) in control soil (C) and in $\mathrm{BCH}$ amended soils combined with inoculums (BI1, BI2) and with additional $N$ fertilizer addition (BI1N, BI2N). Values are presented as means $\pm S D$. Different letters refer to significant differences between treatments (Tukey HSD test, $n=4, p \leq 0.05$ ).

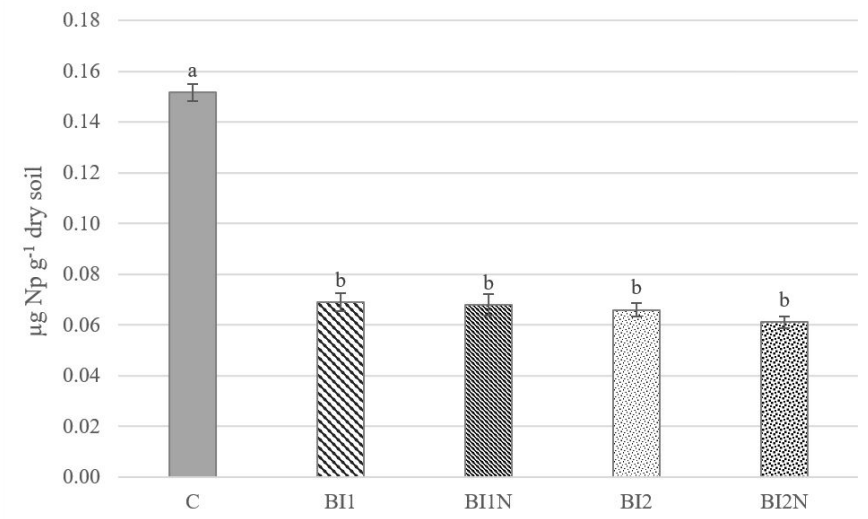

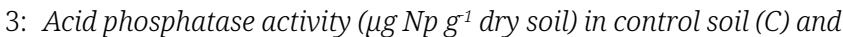
in BCH amended soils combined with inoculums (BI1, BI2) and with additional $N$ fertilizer addition (BI1N, BI2N). Values are presented as means $\pm S D$. Different letters refer to significant differences between treatments (Tukey HSD test, $n=4, p \leq 0.05$ ).

1.6-1.8 values compared to control that ranged

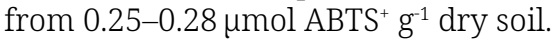

\section{DISCUSSION}

\section{The Effect of the BCH, Bacterial Inoculums and N Fertilizer on Soil Physicochemical Parameters}

$\mathrm{BCH}$ amended soils with bacterial inoculums and $\mathrm{N}$ fertilizer had significantly higher $\mathrm{pH}$ values compared to control soil (Tab. IV). According to Novak et al. (2009) significant pH increase occurred at the higher production temperatures of $\mathrm{BCH}$ due to the concentration of nonpyrolyzed inorganic elements in the feedstock. pH increases to alkaline levels in $\mathrm{BCH}$ amended soils that leads to micronutrients deficiencies with a consequent yield decrease (Chan and $\mathrm{Xu}, 2012$ ). From the other side, studies of Hale et al. (2011) showed no pH nor CEC changes in plain fine loam soil amended with corn stover $\mathrm{BCH}$, microbial inoculums and nutrient solutions, even in the aged form. CEC values displayed quite similar trend with the higher CEC data in BCH amended soils by 8.5\% compared to control soil (Tab. IV), although Bactofil inoculum proved its lower effectiveness being equal to control. Our results are in line with the former report of Liang et al. (2006) where CEC per unit soil $\mathrm{C}$ were up to 1.9 times higher in Anthrosols amended with $\mathrm{BCH}$ compared to the adjacent soils. Studies of He et al. (2017) on straw BCH mixed with regular chemical fertilizers showed CEC increase up to $21.8 \%$ compared to the other treatments, studying paddy soil used for the production of rice and rapeseed.

\section{The Effect of the $\mathrm{BCH}$, Bacterial Inoculums and $N$ Fertilizer on Bacteria Quantity and Soil Enzyme Activities}

The results on total soil bacteria count demonstrated the absence of effect in $\mathrm{BCH}$ 


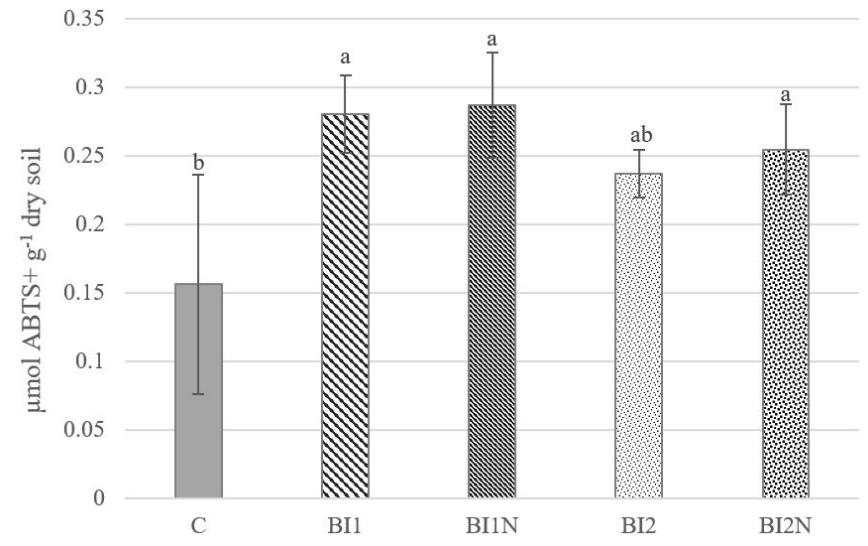

4: Laccase activity ( $\mu$ mol $A B T S^{+} g^{-1}$ dry soil) in control soil (C) and in $B C H$ amended soils combined with inoculums (BI1, BI2) and with additional $N$ fertilizer addition (BI1N, BI2N). Values are presented as means $\pm S D$. Different letters refer to significant differences between treatments (Tukey HSD test, $n=4, p \leq 0.05$ ).

amended soils, as these parameters were equal to control without any additives (Fig. 1). Our results are in line with the studies of Prayogo et al. (2014), where addition of $\mathrm{BCH}$ in rather low concentrations of $0.5 \%$ and $2 \%$ had no significant effect on the amount of total, bacterial or fungal phospholipid fatty acid that indicated bacterial development. Sun et al. (2016a) reported on pine-wood BCH used as a Pseudomonas putida inoculum carrier that does not promote increased shelf life or inoculum efficacy. Whereas former reports of Saxena et al. (2013) stated on beneficial BCH influence combined with Bacillus sp. as a bioinoculant and commercial fertilizer on phosphate solubilizing bacteria abundance in loamy soil.

Urease enzymes are released during the hydrolysis of urea to carbon dioxide and ammonia, that might be assimilated by microbes and plants (Lloyd and Sheaffe, 1973). No effect was observed on urease activity with any amendments, even with $\mathrm{N}$ fertilizers containing urea (Fig. 2). Similar results on urease activity were obtained in Lu et al. (2015) with wheat straw $\mathrm{BCH}$ and $\mathrm{BCH}$ poultry manure compost applied to Aqui-Entisol with maize. Contrary to that, studies of Akça and Namli (2015) demonstrated the opposite effect of the poultry litter $\mathrm{BCH}$ on urease activity in clay loam soil which grew lettuce, tomato and pepper plants, promoting its abundance. Our previous studies stated on promoted plant growth in BI1N and BI2N treatments, where $\mathrm{N}$ compounds were effectively utilized by plant, and Novaferm treatment demonstrated greater effectiveness in terms of bacterial combination promoting plant growth even without $\mathrm{N}$ additives (Mikajlo et al., 2020).

$\mathrm{N}$ fertilizer itself, in turn, can influence acid phosphatase activity positively like in the studies on ammonium nitrate additive under winter wheat cultivation (Lemanowicz, 2011), in the same way as the combined inoculation including Bacillus subtilis promotes acid phosphatase activity along with rhizosphere microbial population in the studies on lettuce in agricultural soil (Kohler et al., 2007). Although in our studies BCH in higher doses had greater suppressing effect compared to mineral additives.

Phosphatase activity values in $\mathrm{BCH}$ amended soils with inoculums and $\mathrm{N}$ fertilizer revealed lower by 53.4-60\% data compared to non-amended soil (Fig. 3). Generally, phosphatase enzymes hydrolyse organic phosphorus (P) compounds with consequent transformation into different forms of inorganic $\mathrm{P}$, that in turn are assimilable by plants (Margalef et al., 2017). Our former studies on total $\mathrm{P}$ content in $\mathrm{BCH}$ amended soils showed no significant differences within treated and control soils after the second lettuce harvest, owing to P consumption by control plants in the first harvest (Mikajlo et al., 2020). This can also be related to higher acid phosphatase activity in non-amended soil. Perhaps this decrease in $\mathrm{BCH}$ amended soils is related to $\mathrm{BCH}$ chemical properties. The results are in line with the former reports on acid phosphatase activity decrease by $18.6 \%$ and $34.0 \%$ for clay loam and silt loam induced by manure $\mathrm{BCH}$ addition that had been detected by Jin et al. (2016) explained by possible probability of substrates chemical blocking by BCH. The confirmation of this hypothesis had been also revealed by Sun et al. (2016b) studying rice straw $\mathrm{BCH}$ and evaluating its effect on the microbial community in biochar niche, while concluding absorption of tested enzymes by $\mathrm{BCH}$ including phosphatase and resulting in its quantitative decrease. The other study of Chen et al. (2013) detected no differences in acid phosphatase activity within control and wheat straw $\mathrm{BCH}$ amended sandy loam soils of rice paddy field in China.

Contrary to phosphatase activity values, laccase activity exhibited the lowest content in control soil (Fig. 4). Generally, laccases play an important 
role in the carbon cycle and have been considered mostly like fungal enzymes, that participate in lignin transformation and other polyphenols, being present in dead plant material and humic substances in soils (Eichlerová et al., 2012). Additional soil additives like $\mathrm{BCH}, \mathrm{N}$ fertilizer and inoculums could alter these processes. Bacterial inoculums along with the UAN fertilizer improved soil laccase activity values. Although Novaferm amended soils revealed laccase activity values similar to the unamended soil, whilst the rest of the $\mathrm{BCH}$ amended soils displayed data by 33.4-44.8\% higher compared to the control soil. In a previous study, we demonstrated that roots colonization by arbuscular mycorrhizal fungi was equal to control or slightly increased in $\mathrm{BCH}$ amended soils without any significant differences between treatments with bacterial and $\mathrm{N}$ fertilizer additives (Mikajlo et al., 2016). According to Gibson et al. (2016) during $\mathrm{BCH}$ abiotic aging process the oxidation of aromatic $\mathrm{C}$ and the introduction of aliphatic $\mathrm{C}-\mathrm{H}$ groups on $\mathrm{BCH}$ occurs, that enhances laccase and peroxidase activities with fungal respiration. Similar results on increased laccase activity in $\mathrm{BCH}$ amended soil had been also found in the studies of Lauber et al. (2009) where no significant shift in the composition of laccase genes between control- and $\mathrm{N}$-fertilized soils had been found nor in the relative abundance of laccase genes. Contrary to these findings, other studies claim on BCH ability to immobilize laccase including its activity decrease owing to $\mathrm{BCH}$ porous surface structure (Taheran et al., 2017; Lonappan et al., 2018; Naghdi et al., 2018). Overall, physicochemical and biological soil activities are highly dependent on $\mathrm{BCH}$ feedstock, means of production and an initial soil state (Lehmann et al., 2011).

\section{CONCLUSION}

Our results showed prosperous effect of inoculums on soil physicochemical properties that was supported by $\mathrm{N}$ fertilization. In addition, Novaferm bacterial combination with $\mathrm{BCH}$ had higher effectiveness when analysing CEC. Moreover, for laccase activity both Bactofil and Novaferm with mineral $\mathrm{N}$ showed increased fungal enzyme values compared to control. Nevertheless, taking into consideration other soil enzyme activities and microbial growth, we may state on $\mathrm{BCH}$ and additives combination ineffectiveness regarding urease and acid phosphatase activity along with total soil bacteria amount. Most probably, high BCH concentrations are not prosperous enough for microbial development in soil. Chosen $\mathrm{BCH}$ concentration needs reconsideration inclining to its reduction and testing its possible influence in comparison with inoculums and $\mathrm{N}$ additives. This investigation needs deeper study aiming to analyse BCH aging in soil for a longer period and its functioning in soil-plant nutrient cycling.

\section{Acknowledgements}

This paper was supported by the project ATCZ42 INTEKO: "Innovation technologies in composting, its application and soil protection"; by the Internal Grant Agency IGA FA MENDELU (Faculty of AgriScience, Mendel University in Brno) No. TP 3/2015 with the support of the Specific University Research Grant (Ministry of Education, Youth and Sports, Czech Republic); by the Erasmus+ mobility program realizing the internship at ISA, Lille (France).

\section{REFERENCES}

AKÇA, M. O. and NAMLI, A. 2015. Effects of poultry litter biochar on soil enzyme activities and tomato, pepper and lettuce plants growth. Eurasian Journal of soil Science, 4(3): 161-168.

ASAI, H., SAMSON, B. K., STEPHAN, H. M., SONGYIKHANGSUTHOR, K., HOMMA, K., KIYONO, Y., INOUE, Y., SHIRAIWA, T. and HORIE, T. 2009. Biochar amendment techniques for upland rice production in Northern Laos. 1. Soil physical properties, leaf SPAD and grain yield. Field Crops Research, 111(1-2): 81-84.

BAILEY, V. L., FANSLER, S. J., SMITH, J. L. and BOLTON, H. 2011. Reconciling apparent variability in effects of biochar amendment on soil enzyme activities by assay optimization. Soil Biology and Biochemistry, 43(2): 296-301.

CHAN, K. Y. and XU, Z. H. 2012. Biochar: Nutrient properties and their enhancement. In: LEHMANN, J. and JOSEPH, S. (Eds.). Biochar for Environmental Management: Science and Technology. Earthscan, pp. 67-84.

CHAN, K. Y., VAN ZWIETEN, L., MESZAROS, I., DOWNIE, A. and JOSEPH, S. 2007. Agronomic values of green waste biochar as a soil amendment. Australian Journal of Soil Research, 45(8): 629-634.

CHEN, J., LIU, X., ZHENG, J., ZHANG, B., LU, H., CHI, Z., PAN, G., LI, L., ZHENG, J., ZHANG, X., WANG, J. and YU, X. 2013. Biochar soil amendment increased bacterial but decreased fungal gene abundance 
with shifts in community structure in a slightly acid rice paddy from Southwest China. Applied Soil Ecology, 71: 33-44.

DOMENE, X., MATTANA, S., HANLEY, K., ENDERS, A. and LEHMANN, J. 2014. Medium-term effects of corn biochar addition on soil biota activities and functions in a temperate soil cropped to corn. Soil Biology and Biochemistry, 72: 152-162.

EICHLEROVÁ, I., ŠNAJDR, J. and BALDRIAN, P. 2012. Laccase activity in soils: Considerations for the measurement of enzyme activity. Chemosphere, 88(10): 1154-1160.

EIVAZI, F. and TABATABAI, M. A. 1977. Phosphatases in soils. Soil Biology and Biochemistry, 9(3): 167-172. GIBSON, C., BERRY, T. D., WANG, R., SPENCER, J. A., JOHNSTON, C. T., JIANG, Y., BIRD, J. A. and FILLEY, T. R. 2016. Weathering of pyrogenic organic matter induces fungal oxidative enzyme response in single culture inoculation experiments. Organic Geochemistry, 92: 32-41.

GUL, S., WHALEN, J. K., THOMAS, B. W., SACHDEVA, V. and DENG, H. 2015. Physico-chemical properties and microbial responses in biochar-amended soils: Mechanisms and future directions. Agriculture, Ecosystems and Environment, 206: 46-59.

HALE, S., HANLEY, K., LEHMANN, J., ZIMMERMAN, A. and CORNELISSEN, G. 2011. Effects of chemical, biological, and physical aging as well as soil addition on the sorption of pyrene to activated carbon and biochar. Environmental Science and Technology, 45(24): 10445-10453.

HE, L., ZHONG, Z. and YANG, H. 2017. Effects on soil quality of biochar and straw amendment in conjunction with chemical fertilizers. Journal of Integrative Agriculture, 16(3): 704-712.

IPPOLITO, J. A., NOVAK, J. M., BUSSCHER, W. J., AHMEDNA, M., REHRAH, D. and WATTS, D. W. 2012. Switchgrass biochar affects two aridisols. Journal of Environment Quality, 41(4): 1123.

JIN, Y., LIANG, X., HE, M., LIU, Y., TIAN, G. and SHI, J. 2016. Manure biochar influence upon soil properties, phosphorus distribution and phosphatase activities: A microcosm incubation study. Chemosphere, 142: 128-135.

KANDELER, E. and GERBER, H. 1988. Short-term assay of soil urease activity using colorimetric determination of ammonium. Biology and Fertility of Soils, 6(1): 68-72.

KOHLER, J., CARAVACA, F., CARRASCO, L. and ROLDÁN, A. 2007. Interactions between a plant growthpromoting rhizobacterium, an AM fungus and a phosphate-solubilising fungus in the rhizosphere of Lactuca sativa. Applied Soil Ecology, 35(3): 480-487.

KUPPUSAMY, S., THAVAMANI, P., MEGHARAJ, M., VENKATESWARLU, K. and NAIDU, R. 2016. Agronomic and remedial benefits and risks of applying biochar to soil: Current knowledge and future research directions. Environment International, 87: 1-12.

LAIRD, D. A., FLEMING, P., DAVIS, D. D., HORTON, R., WANG, B. and KARLEN, D. L. 2010. Impact of biochar amendments on the quality of a typical Midwestern agricultural soil. Geoderma, 158(3-4): 443-449.

LAL, R. 2001. Soil degradation by erosion. Land Degradation and Development, 12(6): 519-539.

LAMMIRATO, C., MILTNER, A. and KAESTNER, M. 2011. Effects of wood char and activated carbon on the hydrolysis of cellobiose by $\beta$-glucosidase from Aspergillus niger. Soil Biology and Biochemistry, 43(9): 1936-1942.

LAUBER, C. L., SINSABAUGH, R. L. and ZAK, D. R. 2009. Laccase gene composition and relative abundance in oak forest soil is not affected by short-term nitrogen fertilization. Microbial Ecology, 57(1): 50-57.

LEHMANN, J. 2007. A handful of carbon. Nature, 447(7141): 143-144.

LEHMANN, J., RILLIG, M. C., THIES, J., MASIELLO, C. A., HOCKADAY, W. C. and CROWLEY, D. 2011. Biochar effects on soil biota - A review. Soil Biology and Biochemistry, 43(9): 1812-1836.

LEMANOWICZ, J. 2011. Phosphatases activity and plant available phosphorus in soil under winter wheat (Triticum aestivum L.) fertilized minerally. Polish Journal of Agronomy, 4(3): 12-15.

LI, N., XIA, Q., NIU, M., PING, Q. and XIAO, H. 2018. Immobilizing Laccase on Different Species Wood Biochar to Remove the Chlorinated Biphenyl in Wastewater. Scientific Reports, 8(1): 13947.

LIANG, B., LEHMANN, J., SOLOMON, D., KINYANGI, J., GROSSMAN, J., O'NEILL, B., SKJEMSTAD, J. O., THIES, J., LUIZÃO, F. J., PETERSEN, J. and NEVES, E. G. 2006. Black carbon increases cation exchange capacity in soils. Soil Science Society of America Journal, 70(5): 1719.

LINDAHL, V. and BAKKEN, L. R. 1995. Evaluation of methods for extraction of bacteria from soil. FEMS Microbiology Ecology, 16(2): 135-142.

LLOYD, A. B. and SHEAFFE, M. J. 1973. Urease activity in soils. Plant and Soil, 39(1): 71-80.

LONAPPAN, L., LIU, Y., ROUISSI, T., BRAR, S. K., VERMA, M. and SURAMPALLI, R. Y. 2018. Adsorptive immobilization of agro-industrially produced crude laccase on various micro-biochars and degradation of diclofenac. Science of the Total Environment, 640-641: 1251-1258.

LU, H., LASHARI, M. S., LIU, X., JI, H., LI, L., ZHENG, J., KIBUE, G. W., JOSEPH, S. and PAN, G. 2015. Changes in soil microbial community structure and enzyme activity with amendment of biochar- 
manure compost and pyroligneous solution in a saline soil from Central China. European Journal of Soil Biology, 70: 67-76.

MAJOR, J., RONDON, M., MOLINA, D., RIHA, S. J. and LEHMANN, J. 2010. Maize yield and nutrition during 4 years after biochar application to a Colombian savanna oxisol. Plant and Soil, 333(1-2): 117-128.

MARGALEF, O., SARDANS, J., FERNÁNDEZ-MARTÍNEZ, M., MOLOWNY-HORAS, R., JANSSENS, I. A., CIAIS, P., GOLL, D., RICHTER, A., OBERSTEINER, M., ASENSIO, D. and PEÑUELAS, J. 2017. Global patterns of phosphatase activity in natural soils. Scientific Reports, 7(1): 1337.

MIKAJLO, I., ANTOSOVSKY, J., DVORACKOVA, H., SVOBODA, Z. and ZAHORA, J. 2016. The effect of inoculated and mitigated by plants biochar on soil microbiota. In: Proceedings of International PhD students conference (MendelNet 2016). Brno: Mendel university in Brno, pp. 117-122.

MIKAJLO, I., POURRUT, B., LOUVEL, B., HYNŠT, J. and ZÁHORA, J. 2020. Plant-soil nitrogen, carbon and phosphorus content after the addition of biochar, bacterial inoculums and $\mathrm{N}$ fertilizer. bioRxiv, preprint server for biology. [Online]. Available at: https://doi.org/10.1101/2020.02.18.954941.

NAGHDI, M., TAHERAN, M., BRAR, S. K., KERMANSHAHI-POUR, A., VERMA, M. and SURAMPALLI, R. Y. 2018. Pinewood nanobiochar: A unique carrier for the immobilization of crude laccase by covalent bonding. International Journal of Biological Macromolecules, 115: 563-571.

NÈBLE, S., CALVERT, V., LE PETIT, J. and CRIQUET, S. 2007. Dynamics of phosphatase activities in a cork oak litter (Quercus suber L.) following sewage sludge application. Soil Biology and Biochemistry, 39(11): 2735-2742.

NOVAK, J. M., LIMA, I., XING, B., GASKIN, J. W., STEINER, C., AHMEDNA, M., REHRAH, D., WATTS, D. W., BUSSCHER, W. J. and SCHOMBERG, H. 2009. Characterization of designer biochar produced at different temperatures and their effects on a loamy sand. Annals of Environmental Science, 3: 195-206.

PLOŠEK, L. 2016. Application of processed biodegradable waste in combination with industrial fertilizers to the soil [in Czech: Aplikace zpracovaného biologicky rozložitelného odpadu v kombinaci s průmyslovými hnojivy do půdy]. Brno: Mendel University in Brno. 144 p.

PRAYOGO, C., JONES, J. E., BAEYENS, J. and BENDING, G. D. 2014. Impact of biochar on mineralisation of $\mathrm{C}$ and $\mathrm{N}$ from soil and willow litter and its relationship with microbial community biomass and structure. Biology and Fertility of Soils, 50(4): 695-702.

SAHA, U. K., SONON, L. and KISSEL, D. E. 2012. Comparison of conductimetric and colorimetric methods with distillation-titration method of analyzing ammonium nitrogen in total Kjeldahl digests. Communications in Soil Science and Plant Analysis, 43(18): 2323-2341.

ŠARAPATKA, B. and BEDNÁR̆, M. 2015. Assessment of potential soil degradation on agricultural land in the Czech Republic. Journal of Environment Quality, 44(1): 154

SAXENA, J., RANA, G. and PANDEY, M. 2013. Impact of addition of biochar along with Bacillus sp. on growth and yield of French beans. Scientia Horticulturae, 162: 351-356.

SPOKAS, K. A., CANTRELL, K. B., NOVAK, J. M., ARCHER, D. W., IPPOLITO, J. A., COLLINS, H. P., BOATENG, A. A., LIMA, I. M., LAMB, M. C., MCALOON, A. J., LENTZ, R. D. and NICHOLS, K. A. 2012. Biochar: a synthesis of its agronomic impact beyond carbon sequestration. Journal of Environment Quality, 41(4): 973.

STEINER, C., GLASER, B., TEIXEIRA, W. G., LEHMANN, J., BLUM, W. E. H. and ZECH, W. 2008. Nitrogen retention and plant uptake on a highly weathered central Amazonian Ferralsol amended with compost and charcoal. Journal of Plant Nutrition and Soil Science, 171(6): 893-899.

SUN, D., HALE, L. and CROWLEY, D. 2016. Nutrient supplementation of pinewood biochar for use as a bacterial inoculum carrier. Biology and Fertility of Soils, 52(4): 515-522.

SUN, D., LAN, Y., XU, E. G., MENG, J. and CHEN, W. 2016. Biochar as a novel niche for culturing microbial communities in composting. Waste Management, 54: 93-100.

SUN, D., MENG, J., XU, E. G. and CHEN, W. 2016. Microbial community structure and predicted bacterial metabolic functions in biochar pellets aged in soil after 34 months. Applied Soil Ecology, 100: 135-143.

TAHERAN, M., NAGHDI, M., BRAR, S. K., KNYSTAUTAS, E. J., VERMA, M. and SURAMPALLI, R. Y. 2017. Degradation of chlortetracycline using immobilized laccase on Polyacrylonitrile-biochar composite nanofibrous membrane. Science of the Total Environment, 605-606: 315-321.

WANG, X., SONG, D., LIANG, G., ZHANG, Q., AI, C. and ZHOU, W. 2015. Maize biochar addition rate influences soil enzyme activity and microbial community composition in a fluvo-aquic soil. Applied Soil Ecology, 96: 265-272.

WU, F., JIA, Z., WANG, S., CHANG, S. X. and STARTSEV, A. 2013. Contrasting effects of wheat straw and its biochar on greenhouse gas emissions and enzyme activities in a Chernozemic soil. Biology and Fertility of Soils, 49(5): 555-565. 


\section{Contact information}

Irina Mikajlo: irina.mikajlo@mendelu.cz (corresponding author) Bertrand Pourrut: bertrand.pourrut@ensat.fr Brice Louvel: brice.louvel@yncrea.fr Jaroslav Hynšt: jaroslav.hynst@ukzuz.cz Jaroslav Záhora: jaroslav.zahora@mendelu.cz 